$\stackrel{\circ}{\text { II }}$

\title{
CHŁOP POLSKI W EUROPIE I AMERYCE JAKO STUDIUM INKORPORACJI GRUP SPOŁECZNYCH I BUDOWANIA WSPÓLNOTY NARODOWEJ
}

\begin{abstract}
Chad Alan Goldberg, Chłop polski w Europie i Ameryce jako studium inkorporacji grup społecznych i budowania wspólnoty narodowej [The Polish Peasant in Europe and America as a Study

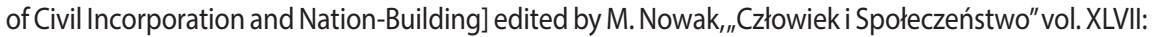
"Chłop polski w Europie i Ameryce" po stu latach [Polish peasant in Europe and America after one hundred years], Poznań 2019, pp. 143-159, Adam Mickiewicz University. Faculty of Social Sciences Press. ISSN 0239-3271.
\end{abstract}

The Polish Peasant in Europe and America, a sprawling masterpiece co-authored by W.I. Thomas and F. Znaniecki and published in five volumes between 1918 and 1921, is a widely acknowledged classic of interwar sociology. One of its signal contributions, and a key reason for its classic status, is what James Carey, in his book on the Chicago school of sociology, calls the social disorganization paradigm. In the United States, the Chicago school of sociology subsequently applied this paradigm to interpret a variety of urban social problems in the 1920s and early 1930s, and it remains influential in studies of crime and violence in American sociology today.

Chad Alan Goldberg, University of Wisconsin-Madison, 8128 W. H. Sewell Social Sciences Building, 1180 Observatory Drive, Madison, WI 53706-1393 USA., e-mail: cagoldberg@wisc.edu

Chłop polski w Europie i Ameryce, obszerne dzieło współautorstwa Williama I. Thomasa i Floriana Znanieckiego, wydane w pięciu tomach w latach 1918-1921, jest powszechnie uznaną, klasyczną pozycją socjologii międzywojennej. Jedną z głównych przyczyn kanoniczności dzieła dla współczesnej socjologii i niepodważalnego wkładu zawartych w nim badań jest zjawisko, które James Carey w swojej pracy dotyczącej szkoły chicagowskiej określił 
terminem „paradygmat dezorganizacji społecznej” (Carey, 1975: 95-120). W Stanach Zjednoczonych szkoła chicagowska zastosowała ten paradygmat jako narzędzie interpretacji różnorodnych miejskich problemów społecznych lat dwudziestych i wczesnych lat trzydziestych XX w., jego wpływ po dziś dzień jest zaś obecny w amerykańskiej socjologii, w badaniach nad przestępczością i przemocą (Faris, 1967: 87; Matthews, 1977: 100)1․

Paradygmat dezorganizacji społecznej za punkt wyjścia przyjmuje organizację społeczną grupy pierwotnej. „Zasady zachowania i działania postrzegane jako zgodne lub niezgodne z tymi zasadami stanowią [...] instytucje społeczne”, piszą Thomas i Znaniecki, „zaś wszystkie instytucje znajdujące się w konkretnej grupie społecznej stanowią organizację społeczną tejże grupy” (Thomas i Znaniecki, 1974: 32-33). Thomas określa grupy pierwotne jako „te społeczności, które poprzez więzy pokrewieństwa, izolację od innych grup [i] dobrowolne przyjęcie pewnych zbiorów definicji zapewniają emocjonalną jednomyślność wśród swoich członków” (Thomas, 1966: 168)². Grupy te określić można jako pierwotne zarówno w sensie logicznym, jak i chronologicznym. Pierwszy i drugi tom Chłopa polskiego... poświęcony jest „organizacji chłopskich grup pierwotnych”, w tym wypadku rodzinie i wspólnocie, oraz „częściowej ewolucji wspomnianego systemu organizacji pod wpływem rozwoju przemysłowego i imigracji do Ameryki i Niemiec" (Thomas i Znaniecki, 1974: VIII) ${ }^{3}$.

Zgodnie z powyższymi uwagami Thomas i Znaniecki postrzegali rozwój kapitalistyczny i migrację jako posiadające główne dezorganizujące wpływy na grupy pierwotne polskich chłopów. Dezorganizacja społeczna, jak pisali, odnosi się do „zmniejszenia wpływu istniejących społecznych reguł zachowania na poszczególnych członków grupy. [...] Nie chodzi tu o przestrzeganie bądź zniesienie jakiejkolwiek konkretnej normy zachowania wskazującej na status danej społeczności, ale o pytanie, czy istnieją wspólne zasady i jak są one przestrzegane” (Thomas i Znaniecki, 1974: 1128, 1171). W trzecim tomie Chłopa polskiego... wykorzystano autobiografię polskiego imigranta, aby zilustrować związane z powyższą tematyką, ale naukowo odrębne zjawisko osobistej dezorganizacji, podczas gdy piąty tom koncentruje się na dezorganizacji społecznej doświadczanej przez polskiego emigranta w Ameryce.

\footnotetext{
${ }^{1}$ Przegląd najnowszych teorii dezorganizacji społecznej dostępny jest w Bellair, 2017.

${ }^{2}$ Artykuł ten został pierwotnie opublikowany w 1917 r. pod tytułem The Persistence of Primary Group Norms in Present Day Society.

${ }^{3}$ Thomas i Znaniecki zaczerpnęli swoją koncepcję organizacji i dezorganizacji społecznej z prac amerykańskiego socjologa Charlesa H. Cooleya, poddając ją twórczemu opracowaniu i modyfikacji (por. Cooley, 1925).
} 
Dla Thomasa i Znanieckiego dezorganizacja społeczna była, przynajmniej potencjalnie, zjawiskiem przejściowym, po którym istniała możliwość ostatecznej reintegracji jednostek w ramach nowego porządku społecznego. Autorzy podkreślali, że wspomniany proces reorganizacji „nie polega na zwykłym wzmocnieniu chylącej się ku upadkowi organizacji społecznej, ale na tworzeniu nowych schematów zachowań i nowych instytucji lepiej dostosowanych do zmienionych wymagań grupy” (Thomas i Znaniecki, 1974: 1130). Dlatego też pierwotne postawy rodziny chłopskiej, ściśle ukierunkowane na grupę rodzinną i wspólnotę, nie mogły pozostać niezmienione po tym, jak członkowie rodziny doświadczyli procesu indywidualizacji. Nic jednak nie stało na przeszkodzie, by rodzina została zreorganizowana według „nowych zasad - opierających się na moralnej, przemyślanej koordynacji i harmonizacji postaw indywidualnych dla osiągnięcia wspólnych celów" (Thomas i Znaniecki, 1974: 1169-1170).

Badacze nazwali ten proces społeczną rekonstrukcją, zapożyczając termin z amerykańskiej szkoły filozofii zwanej pragmatyzmem. Rekonstrukcja owa pociągała za sobą racjonalną i dobrowolną współpracę zamiast przymusu, aktywną i inteligentną solidarność z członkami grupy zamiast bezmyślnego konformizmu, ukierunkowanie postaw indywidualistycznych na wspólne i społecznie użyteczne cele zamiast ich tłumienia. W celu zanalizowania tej możliwości w czwartym tomie Chłopa polskiego... omówiono „rozpad grupy pierwotnej oraz społeczną i polityczną reorganizację i unifikację społeczności chłopskich w Polsce na nowym gruncie racjonalnej współpracy” (Thomas i Znaniecki, 1974: VIII).

Celem niniejszego artykułu jest historyczne umiejscowienie kategorii paradygmatu dezorganizacji społecznej. Jakie są historyczne podstawy, na których opiera się ten paradygmat? Jak wskazał socjolog Pierre Bourdieu, kategorie teorii społecznej zazwyczaj omawiane są w podejściu dualistycznym, podejście to z kolei nierzadko opiera się na historycznych opozycjach. Bourdieu twierdzi, iż „moglibyśmy wykazać [...], że historyczna opozycja między Francją a Niemcami posłużyła jako podstawa (nieświadoma i tłumiona)” dla „wielkich alternatyw” cywilizacji i kultury (Bourdieu, 2008: 225)4. Jak pokazałem w innych moich pracach, kontrast między cywilizacją a kulturą opierał się również na historycznej opozycji pomiędzy Judentum a Deutschtum (Goldberg, 2017: 43-75). Także i ten artykuł stawia sobie za cel ukazanie, w jaki sposób Thomas i Znaniecki powoływali się na rzeczywiste lub rzekome

${ }^{4}$ Historyczne podłoże teorii społecznej prezentuje również Calhoun (1996: 305-337). Pogłębioną analizę cywilizacji i kultury przedstawia Elias (1978: 3-34). 
różnice między Polakami a Żydami w celu wyjaśnienia paradygmatu społecznej dezorganizacji. Kontrasty między Polakami a Żydami, które Thomas i Znaniecki wielokrotnie wskazywali w swoim dziele, stanowią ważną (choć w późniejszych czasach zapomnianą) historyczną podstawę teoretycznych kategorii organizacji grupy pierwotnej, dezorganizacji społecznej i reorganizacji społecznej bądź rekonstrukcji. W niniejszych rozważaniach postaram się wykazać słuszność tej tezy, posiłkując się trzystopniowym porównaniem. Posłużę się w tym celu analizą komparatystyczną Chłopa polskiego w Europie i Ameryce z Old World Traits Transplanted, książką opublikowaną w $1921 \mathrm{r}$. i w dużej części napisaną przez Thomasa, choć jej autorstwo przypisywane jest amerykańskim socjologom Robertowi Parkowi i Herbertowi Millerowi, w związku ze skandalicznymi okolicznościami, w jakich Thomas został wydalony z University of Chicago. Podejście komparatystyczne do obu tekstów umożliwia dalsze porównanie reorganizacji społecznej na terytorium Polski i Stanów Zjednoczonych. W ostatnim fragmencie mojego tekstu podkreślę różnice między Polakami a Żydami w obu tych kontekstach narodowych ${ }^{5}$.

Skupmy się najpierw na kontekście polskim. Przypomnijmy, że nie tylko migracja do Nowego Świata, ale także rozwój kapitalizmu w Starym Świecie zdezorganizował chłopską grupę społeczną. Powyższy stan rzeczy sprawił, że Thomas i Znaniecki opisywali Żydów w Polsce jako główne źródło dezorganizacji. Autorzy pisali, iż stojąc „poza polskim życiem społecznym” i „społeczeństwem polskim”, „Żydzi byli w dużej mierze przedstawicielami gospodarki kapitalistycznej” (Thomas i Znaniecki, 1974: 130, 133). Jako reprezentanci tejże gospodarki, wprowadzili oni chłopa w nowy, obcy i indywidualistyczny etos ekonomicznego racjonalizmu, który kłócił się z:

tradycyjną gospodarką rodzinną, gdzie wartości ekonomiczne są nadal w dużej mierze jakościowe, jeszcze niepodporządkowane idei ilości, dominującą zaś postawą jest zainteresowanie dostatnim życiem, a nie tendencja do wzbogacania się (Thomas i Znaniecki, 1974: 156).

Co więcej, badacze wysunęli argument, że „dezorganizacja spowodowana przez obcych” sięgała „znacznie głębiej” niż dezorganizacja społeczna wywołana przez zagraniczną imigrację chłopa polskiego. Do „obcych” zaliczali takie osoby jak „żydowski sklepikarz”, który „osiedlił się wśród miejscowej ludności, przynosząc ze sobą inne obyczaje”, lecz „nie dokonał asymilacji” przede wszystkim z powodu „kwestii rasowych” (Thomas

${ }^{5}$ Wspomniane już trzystopniowe porównanie zostało wcześniej zastosowane w moim artykule: Goldberg, 2017: 79-83, 93-100. 
i Znaniecki, 1974: 1200) ${ }^{6}$. Ponadto autorzy podkreślali, że Żydzi, jako społeczni nosiciele indywidualizmu gospodarczego, nie tylko stanowili podstawę do dezorganizacji pierwotnych grup chłopskich w Polsce, lecz również konkurowali ze spółdzielczymi inicjatywami chłopskimi, które badacze postrzegali jako podstawę społecznej reorganizacji i odbudowy życia chłopskiego w Polsce ${ }^{7}$.

Oprócz opisania Żydów jako propagatorów indywidualizmu gospodarczego Thomas i Znaniecki prześledzili też inną formę wpływu żydowskiego, dezorganizującego grupę pierwotną: przestępczość i sprzyjanie zachowaniom dewiacyjnym. „Żydowski sklepikarz na wsi”, pisali,

zwykle jest także handlarzem nielicencjonowanego alkoholu, bankierem pożyczającym pieniądze na lichwę, często również paserem oraz (w pobliżu granicy) kontrabandzistą [...]. W dokumentach [fragmenty polskich gazet opublikowanych w latach 1892-1913 - dop. Ch.A.G.] widzieliśmy metody, za pomocą których właściciel sklepu uczy chłopa palenia, picia i wreszcie kradzieży (Thomas i Znaniecki, 1974: 1200-1201) ${ }^{8}$.

Ten negatywny pogląd dotyczący Żydów współgra z tradycyjnymi uprzedzeniami polskiej klasy szlacheckiej, która obwiniała Żydów za biedę i pijaństwo chłopów (Vital, 1999: 88, 90). Jak zauważa historyk David Vital, z historycznego punktu widzenia Żydzi byli ,jedynie dzierżawcami przyznanego szlachcie monopolu na prawo do destylacji alkoholu i handlu nim” i „nie było powodu przypuszczać, że gdyby Żydzi zostali wyeliminowani z tego łańcucha zależności, inni nie zajęliby ich miejsca”, jakkolwiek te aspekty problemu były zazwyczaj ignorowane (Thomas i Znaniecki, 1974: 95). Wprawdzie przywołane cechy Żydów odzwierciedlają tradycyjne

${ }^{6}$ Thomas i Znaniecki wielokrotnie podkreślali, że polscy chłopi nauczyli się indywidualizmu ekonomicznego poprzez kontakty z Żydami i innymi mniejszościami etnicznymi (Thomas i Znaniecki, 1974: 184-186, 292, 1203-1204). Podkreślają także pogardliwy stosunek chłopów do stereotypu Żyda jako zajmującego się zarabianiem pieniędzy (Thomas i Znaniecki, 1974: 292, 448, 501). Opis Żydów jako obcych jest prawdopodobnie aluzją do dzieła Georga Simmla Obcy (Der Fremde), opublikowanego w 1908 r. Drugie jego wydanie pojawia się w: Simmel i Levine, 1971: 143-149.

7 Thomas i Znaniecki wspominają o konkurencji, jaką Żydzi stanowili dla chłopskich spółdzielni (Thomas i Znaniecki, 1974: 369, 428, 1216-1217, 1409-1410). Badacze nawiązują do kwestii spółdzielni jako podstawy reorganizacji i rekonstrukcji społecznej (Thomas i Znaniecki, 1974: 1174, 1400-1402, 1423-1424, 1431, 1442, 1826-1827).

${ }^{8}$ Na kolejnych stronach pojawia się także, przedstawiony przez polskiego księdza, wizerunek Żyda demoralizującego polskiego chłopa na gruncie moralnym i seksualnym (Thomas i Znaniecki, 1974: 1241-1243). 
uprzedzenia polskiej szlachty, prawdopodobnie jednak znalazły się one w Chłopie polskim... z powodu Znanieckiego, który urodził się w rodzinie szlacheckiej.

Żydzi, których Thomas i Znaniecki wyraźnie postrzegali jako dezorganizatorów grup społecznych w Starym Świecie, w Nowym Świecie wnieśli swój własny potencjał twórczej reorganizacji. Chociaż Thomas nigdy nie ukończył i nie opublikował swojego zamierzonego studium Żydów w Europie i Ameryce, Old World Traits Transplanted dostarcza pewnych wskazówek na temat analizy, którą rozwinął we współpracy z amerykańskimi socjologami Parkiem i Millerem (Park i Miller, 1921) ${ }^{9}$. Na zlecenie Carnegie Corporation's Americanization Studies zidentyfikowano Włochów, Polaków i Żydów jako trzy największe grupy nowych imigrantów w Stanach Zjednoczonych; w przybliżeniu były one równe pod względem liczby, każda zaś grupa liczyła od 3 milionów do 3,3 miliona członków w momencie publikacji książki w 1921 r. (Park i Miller, 1921: 225). Autorzy sugerowali jednak, że owe trzy grupy uosabiały różne etapy przechodzenia imigrantów do miejskiej cywilizacji Ameryki.

Włosi w Ameryce utożsamiani byli z początkowym stadium organizacji grupy pierwotnej w warunkach transformacji: zachowali wszelkie korzyści płynące ze swojej etniczności „dłużej niż wiele innych narodowości”, ich „¿̇ycie rodzinne i wspólnotowe” było „pełne czułości i intymności”, a poczucie więzi między poszczególnymi członkami grupy „było wystarczająco silne, aby zapobiec tej demoralizacji drugiego pokolenia, która charakteryzuje Polaków i, do pewnego stopnia, Żydów” (Park i Miller, 1921: 241).

Polacy, bardziej niż pozostałe dwie wspomniane grupy imigrantów, stanowili przykład krytycznego etapu transformacji i dezorganizacji społecznej: polskie społeczności w Ameryce nie „dawały możliwości tworzenia takich struktur organizacyjnych, które pomagałyby ich członkom w przystosowaniu się do skomplikowanego życia na obczyźnie”, a także zaniedbywały zdemoralizowanych członków wspólnoty, pozwalając, aby zajęły się nimi amerykańskie „organizacje charytatywne, stowarzyszenia pomocy prawnej i sądy dla nieletnich”; poza powyższymi przykładami polski imigrant wykazywał jednak „niewielką skłonność do uczestnictwa w amerykańskim życiu społecznym i instytucjonalnym” (Park i Miller, 1921: 227-229, 232-234).

${ }^{9}$ Thomas rozpoczął badania nad Żydami w 1918 r. Nauczył się nawet jidysz w celu ich przeprowadzenia, a żeby je ukończyć, otrzymał grant Social Science Research Council. W połowie lat trzydziestych XX w. rozpoczął negocjacje z wydawcami w sprawie opublikowania książki (Bressler, 1952b: 563; Janowitz, 1966: XXVIII). 
Charakterystyka ta była zbieżna z oceną, której Thomas i Znaniecki dokonali uprzednio w Chłopie polskim..., gdzie odnotowują, że „w porównaniu na przykład z żydowskimi instytucjami charytatywnymi Polacy w Ameryce mają niewiele do pokazania w tej kwestii” (Thomas i Znaniecki, 1974: 1533-1538).

Autorzy Old World Traits Transplanted sugerowali, że Żydzi stanowią przykład trzeciej fazy rekonstrukcji: „Żydzi, znacznie bardziej niż jakakolwiek inna grupa imigrantów, uciekają się do refleksyjnej aktywności społecznej i uzupełniają tradycyjne formy zbiorowe, odtwarzane w sposób spontaniczny, o nowe, świadome formy organizacji” (Park i Miller, 1921: 235-236) ${ }^{10}$. Thomas, Park i Miller wskazali jako główny przykład tej refleksyjnej aktywności społecznej żydowską organizację Kehilah w Nowym Jorku - przeprowadzoną w latach 1909-1922 eksperymentalną próbę zapewnienia rosnącej populacji żydowskiej miasta jednolitej i demokratycznej struktury wspólnotowej (Park i Miller, 1921: 236; Goren, 1970) ${ }^{11}$. Kehilah została utworzona w reakcji na publiczne oskarżenie z $1908 \mathrm{r}$. (później wycofane) komisarza policji w Nowym Jorku Theodore’a Binghama, który miał stwierdzić, że połowa nowojorskich przestępców ma żydowskie pochodzenie, co zostało uznane przez przedstawicieli gminy żydowskiej za niepokojący znak dostrzeganej dezorganizacji społecznej (Goren, 1970: 25-30). Po raz pierwszy Kehilah zapewniła stałą, instytucjonalną podstawę współpracy między zamożnymi, zasymilowanymi, zamieszkałymi w bogatszych dzielnicach miasta niemieckimi Żydami a ubogimi, wschodnioeuropejskimi Żydami z centrum miasta, posługującymi się jidysz. Mówiąc konkretniej, organizacja ta starała się pośredniczyć w kwestiach filantropijnych i religijnych, polepszać stan edukacji Żydów, pośredniczyć w sporach między robotnikami żydowskimi a żydowskimi pracodawcami i redukować poziom przestępstw popełnianych przez członków wspólnoty żydowskiej. Owa eksperymentalna forma reorganizacji

10 „Grupy imigranckie muszą prędzej czy później odwołać się do refleksyjnej aktywności społecznej, muszą uzupełniać spontaniczną reprodukcję starych form społecznych poprzez nową, świadomą organizację” (Thomas i Znaniecki, 1974: 1471).

${ }^{11}$ Kehilah (הליהק) oznacza po prostu społeczność w języku hebrajskim; termin ten może odnosić się do każdej zorganizowanej żydowskiej struktury wspólnotowej. Instytucja istniała również w Polsce, ale niekoniecznie była przykładem reorganizacji społecznej. W powojennej Polsce lokalna kehilah była „definiowana przez polskie ustawodawstwo jako instytucja zasadniczo religijna i zdominowana, częściowo dzięki interwencji rządu, przez przedstawicieli ortodoksyjnego, antynarodowego żydostwa” (Mendelsohn, 1983: 34-35, 39). 
społecznej była szczególnie niezwykła ze względu na gwałtowny wzrost liczby ludności żydowskiej w Nowym Jorku (głównie imigrantów i ich dzieci) z 600 tysięcy w 1900 r. do 1,5 miliona w 1915 r. i prawie 2 milionów w 1925 r., co uczyniło społeczność nowojorską największą miejską społecznością żydowską na świecie (Gartner, 2001: 217, 277) ${ }^{12}$. Co więcej, Żydzi zostali wyróżnieni w analizie zawartej w Old World Traits Transplanted nie tylko dzięki postępowi w reorganizacji ogromnej i (zgodnie z niektórymi relacjami) poważnie zdezorganizowanej wspólnoty, ale także dzięki temu, że reorganizacja ta była w dużej mierze ich własnym osiągnięciem, w przeciwieństwie do polskiego chłopstwa, którego reorganizacja w Polsce prowadzona była głównie odgórnie i z zewnątrz, w szczególności przez polską „górną warstwę społeczną” (Thomas i Znaniecki, 1974: 1121-1122, 1215, 1307). Należy też pamiętać, że ten żydowski eksperyment został przeprowadzony, podobnie jak „historyczny eksperyment” podczas reorganizacji społecznej w Polsce sprzed 1918 r., bez udziału i różnych form nacisku władzy państwowej ${ }^{13}$.

Thomas postrzegał prasę wydawaną w jidysz, wespół z nowojorską Kehilah, jako kolejny obiecujący znak twórczej reorganizacji. Badacz szczególnie interesował się gazetą „Forverts”, największym (pod względem rozpowszechniania) z czterech głównych nowojorskich dzienników w jidysz oraz sekcją Bintl Brief („paczka listów”), w której redaktorzy dostarczali informacji, porad i pomocy w odpowiedzi na listowne pytania czytelników, opisujące typowe problemy, jakie napotykali imigranci lub ich dzieci podczas asymilacji w Nowym Świecie. Thomas uznawał Bintl Brief za skuteczny sposób przedstawiania członkom wspólnoty definiowalnych ram sytuacyjnych oraz mobilizowania opinii publicznej do egzekwowania odpowiednich reakcji na owe ramy; w ten sposób prasa publikowana

12 Dla porównania: w Warszawie w 1931 r. mieszkało jedynie 350 tysięcy Żydów, mimo że procentowy udział Żydów w całkowitej populacji Warszawy był wyższy (około 30\%) niż analogiczny w Nowym Jorku w 1915 r. (około 25\%). O populacji żydowskiej w głównych miastach Polski pisze także Ezra Mendelsohn (1983: 23).

13 Jako że rekonstrukcja społeczna w kontekście polskim miała miejsce przed rokiem 1918, gdy nie istniało niepodległe państwo polskie, ten „eksperyment historyczny” miał ogólne znaczenie socjologiczne dla „najważniejszego problemu współczesnych czasów jak przejść od narodowego typu wspólnoty, w którym usługi publiczne są rygorystycznie wymagane, porządek publiczny zaś egzekwowany poprzez przymus, do innego typu, w którym nie tylko niewielka mniejszość, ale i większość, obecnie bierna kulturowo, dobrowolnie przyczyniają się do tworzenia porządku społecznego i postępu kulturowego” (Thomas i Znaniecki, 1974: 1306). 
w jidysz działała jako nowy instrument kontroli społecznej (Bressler, 1952a: 2, 4, 15-16, 78, 82, 398-400, 418). Thomas nie miał tutaj na myśli dominacji jednej grupy nad drugą, ale raczej zdolność danej społeczności do samoregulacji, zgodnie z pożądanymi przez nią zasadami i wartościami. W związku z tym kontrola społeczna nie była produktem „nakazów i zakazów”, aby użyć wyrażenia Thomasa, ale wymagała świadomej refleksji i aktywnego uczestnictwa jednostek w danej społeczności; to zaś zależało, jak ujął to filozof pragmatyzmu i psycholog społeczny George Herbert Mead, od zdolności jednostek do „przyjmowania postaw innych, z którymi są razem zaangażowani w dążeniu do wspólnego celu"14. W tym przypadku „redaktor naczelny dziennika postrzegany jest jako egzekutor pożądanych standardów interakcji rodzinnych i społecznościowych, działając za pomocą i zgodą opinii publicznej” (Bressler, 1952a: 440).

Prasa publikowana w jidysz była środkiem nie tylko do samoregulacji społeczności, ale także do jej rozwoju ${ }^{15}$. W swojej książce The Immigrant Press and Its Control z 1922 r. Park zasugerował, że czasopisma pisane w jidysz stanowiły wyraźny przykład tych procesów, szczególnie w przypadku żydowskiej wspólnoty z Nowego Jorku: „Żadne inne gazety [...] nie wykreowały tak dużej społeczności czytelniczej [...] ani nie miały tak silnego wpływu na opinie, myśli i aspiracje społeczności, dla której istnieją" (Park, 1922: 89). Park uznawał to stwierdzenie za prawdziwe z dwóch powodów. Prasa imigrancka sprzyjała „poczuciu solidarności etnicznej i narodowościowej” wśród czytelników, przeważając tym samym

14 „Najstarszą, ale i najbardziej trwałą formą techniki społecznej jest «nakazywanie i zakazywanie» - to znaczy rozwiązywanie sytuacji kryzysowych poprzez podjęcie arbitralnej decyzji o eliminacji niepożądanego zjawiska lub równie arbitralnego postanowienia o nagradzaniu pożądanych zachowań oraz stosowanie arbitralnego fizycznego działania mającego na celu wprowadzenie tych decyzji w życie” (Thomas i Znaniecki, 1974: 3). O kontroli społecznej pisze także Morris Janowitz (1975: 82-108) - Mead jest cytowany na s. 83.

15 Thomas i Znaniecki w Chłopie polskim... także podkreślali rolę prasy w rekonstrukcji społecznej. Zwłaszcza tam, gdzie brakowało władzy państwowej i militarnej, „jedynym instrumentem, za pomocą którego można było zbudować system grupy wtórnej ponad organizacją grupy pierwotnej, była prasa, a jedyną formą, którą ów system grup wtórnych mógł przyjąć, był kontekst szerszej społeczności, w której komunikacja za pośrednictwem słowa drukowanego zajęła miejsce bezpośredniego kontaktu osobistego, abstrakcyjna solidarność na gruncie moralnym przejęła zaś rolę konkretnej solidarności społecznej” (Thomas i Znaniecki, 1974: 1368-1369). W podobnej dyskusji na temat roli gazet w kreowaniu wyobrażonych społeczności bierze też udział Benedict Anderson (1991: 33-36, 61-64). 
nad bardziej ograniczonymi i prowincjonalnymi formami identyfikacji społecznej. Według badacza wyjaśniło to, dlaczego Żydzi w Ameryce, pomimo tak różnego pochodzenia kulturowego i geograficznego, osiągnęli „,stopień solidarności i organizacji społecznej skuteczniejszy niż gdziekolwiek indziej od czasu exodusu" (Park, 1922: 294). W tym samym okresie rdzennie amerykańska opinia publiczna „zaczęła zwracać uwagę na obcojęzyczne gazety” oraz dyskutować i cytować wyrażone tam opinie. „Jeśli imigranccy redaktorzy i czytelnicy wiedzą, że ich artykuły i listy są czytane poza ich własną wspólnotą językową, że Ameryka jest zainteresowana tym, co wspólnota ta mówi, i bierze pod uwagę jej opinie - to właśnie ustanawia miarę kontroli” (Park, 1922: 466-467). Park nie miał tu bynajmniej na myśli anglosaskiej kontroli nad imigrantami. Wyobrażał sobie raczej, że imigranci i rodowici Amerykanie stają się przez to członkami tej samej szerszej społeczności, za pośrednictwem której mogą komunikować się i współpracować w celu osiągnięcia wspólnych celów i unormowania regulacji społecznych.

Według Thomasa, Parka i Millera instytucje imigranckie, takie jak żydowska Kehilah i prasa publikowana w jidysz, nie były wyrazem etnicznego lub narodowego separatyzmu, ale „próbą uczestnictwa w amerykańskim życiu” (Park i Miller, 1921: 143-144). Pod tym względem również doświadczenia żydowskie w Europie i Ameryce są, jak się wydaje, studium kontrastów. Z jednej strony, jak zauważyli Thomas i Znaniecki, Żydzi zostali wykluczeni z ważnych aspektów życia szerszej społeczności narodowej tworzonej w niepodległej Polsce po 1918 r. Opisywali oni Żydów jako „rasę o najmniejszym poziomie asymilacji”, wielokrotnie podkreślali także silny związek między poczuciem polskości a katolicyzmem, zauważając jednocześnie, że ludność zamieszkująca polskie miasta miała mniejsze możliwości zapewnienia krajowi ekonomicznej podstawy jedności narodowej niż chłopi, po części z powodu „dużej liczby osób pochodzenia żydowskiego zamieszkujących ośrodki miejskie" (Thomas i Znaniecki, 1974: 85, 1383, 1394, 1441, 1446-1448, 1460) ${ }^{16}$. Jak zauważa historyk Lloyd Gartner, wszystkie polskie partie polityczne w II Rzeczypospolitej skłaniały się ku opcji polskiego państwa narodowego, mimo że jedna trzecia ludności kraju, w tym ponad 2,5 miliona Żydów w 1921 r., należała do mniejszości narodowych lub religijnych, co czyniło Polskę głównym

${ }^{16}$ Dodają oni także, iż tam, gdzie identyfikowanie się z „katolicyzmem i polonizmem” było niedostateczne, jak w przypadku „polskich protestantów lub spolonizowanych Żydów”, narodowościowe proklamacje opierały się na „bardziej ogólnych zasadach” (Thomas i Znaniecki, 1974: 1460). 
celem powojennych żądań dotyczących praw mniejszości narodowych. Polscy nacjonaliści stawiali opór tym żądaniom, „serie pogromów i ataków, których nowy rząd nie tylko nie karał, ale nawet nie powstrzymywał", wyraźnie zaś ukazywały, że „nie tylko pełna równość Żydów w nowym państwie polskim została uznana za nie do zaakceptowania, ale również prawa mniejszości” (Gartner, 2001: 282-283) ${ }^{17}$.

Z kolei w przypadku Ameryki, jako że społeczna reorganizacja imigrantów w tym kraju propagowała ich udział w społeczeństwie amerykańskim, można ją zrównać z asymilacją. Ale co w tym kontekście oznacza asymilacja? Uważna lektura dzieła Old World Traits Transplanted sugeruje, że jego autorzy nie myśleli o asymilacji przede wszystkim jako o sposobie zachowania istniejącej kultury anglosaskiej lub promowania całkowitej z nią zgodności, ale raczej jako o sposobie organizowania demokratycznej opinii publicznej, której to organizacja stanowiła pilną potrzebę społeczną, o czym wspomina chociażby filozof pragmatyk John Dewey w swojej książce z 1927 r. The Public and Its Problems (Dewey, 1954). Thomas, Park i Miller założyli, że niektóre stosunki społeczne wytwarzają też konsekwencje dla osób, które nie są w nie bezpośrednio zaangażowane. Społeczeństwo, składające się ze wszystkich tych, których dotykają dane zmiany, organizuje się, aby zrozumieć i poradzić sobie z konsekwencjami wystarczająco ważnymi, by trzeba je było poddać kontroli społecznej. Badacze ci (podobnie jak później Dewey) twierdzili, że niebywały rozwój współzależności we współczesnych społeczeństwach pomnożył jeszcze owe konsekwencje, sprawiając, że organizacja nowej i rozbudowanej opinii publicznej stała się paląco potrzebna. „Parowóz, instytucja poczty, telegraf, prasa [...] rozwiązały problem odległości”, tak więc na warunki codziennego życia pojedynczych ludzi „miały także niebywały wpływ wydarzenia zachodzące bez ich wiedzy, tysiące mil stąd”, pozbawiając ich tym samym kontroli nad systemem relacji międzyludzkich, w którym przyszło im zaistnieć (Park i Miller, 1921: 261-262). Imigracja była jednym z aspektów szerszego problemu organizacji demokratycznej opinii publicznej w nowych warunkach. Żadna wspólnotowość nie była możliwa bez zdolności wzajemnego zrozumienia, wzajemne zrozumienie z kolei wymagało „zbioru wspólnych wspomnień”. „Twierdzenie to jest szczególnie prawdziwe w demokracji”, pisali badacze, „gdzie w zamierzeniu instytucje państwowe powinny reagować na opinię publiczną. Opinia publiczna może zaistnieć tylko pod warunkiem, że osoby tworzące społeczeństwo

17 Zob. też Mendelsohn, 1983: 32-83. Na temat praw mniejszości wypowiada się również Carole Fink (2004). 
będą w stanie żyć i myśleć w tym samym świecie”. W tym celu imigranci powinni nauczyć się ,języka kraju i historii ludzi, wśród których postanowili zamieszkać”, podobnie jak rodowici Amerykanie powinni zapoznać się z „historią i życiem społecznym krajów, z których pochodzą imigranci” (Park i Miller, 1921: 270-271). Ponieważ celem tej asymilacji ma być uczynienie imigranta członkiem społeczności, a społeczeństwo demokratyczne wymaga aktywnego udziału w rozwiązywaniu zbiorowych problemów poprzez komunikację, asymilacja nie może być biernym doświadczeniem. Wręcz przeciwnie, Thomas, Park i Miller oczekiwali, że imigrant przyczyni się, a także podzieli „kapitał wiedzy, doświadczeń, przeżyć i ideałów wspólnych dla całej społeczności” (Park i Miller, 1921: 271). Jak to ujął Park rok później, „to raczej uczestnictwo w danej społeczności, nie zaś poddanie się jej lub całkowita zgodność z nią czyni Amerykanów z ludzi urodzonych poza granicami tego kraju” (Park, 1922: 88).

Z powyżej omówionej dyskusji jasno wynika, że budowanie narodu oraz inkorporacja wartości obywatelskich wśród zewnętrznych wspólnot w Polsce i Ameryce były podstawowymi warunkami dla stworzenia paradygmatu dezorganizacji społecznej ${ }^{18}$. Chociaż Chłop polski w Europie i Ameryce nie jest powszechnie postrzegany jako dzieło wywodzące się z dziedziny socjologii politycznej, jego autorzy ściśle powiązali reorganizację społeczną i budowanie narodu. Na terytorium Polski reorganizacja społeczna polegała na rozszerzeniu „zasady wspólnoty” na „wszystkie te elementy społeczne, z którymi chłopska grupa pierwotna” zetknęła się, ostatecznie zaś „nawet na cały naród” (Thomas i Znaniecki, 1974: 1305). Reorganizacja społeczna miała zatem swoje źródło w „,[polskich] aspiracjach narodowościowych” oraz „ich ostatecznym celu wyznaczonym przez ideał narodowy” (Thomas i Znaniecki, 1974: 1459). W Stanach Zjednoczonych reorganizacja społeczna była z kolei powiązana z amerykanizacją imigrantów. Dla Thomasa i pozostałych badaczy amerykanizacja nie oznaczała włączenia imigrantów w istniejący porządek społeczny, na który nie mieli wpływu, ale raczej ich aktywny udział w tworzeniu szerszej, bardziej rozwiniętej społeczności, a więc w procesie narodowej odbudowy.

${ }^{18}$ Termin „budowanie narodu” zapożyczony został z dzieła Reinharda Bendixa z 1964 r. (Bendix, 1996). Autor ten wskazał, że kraje, które odzyskały niepodległość, stanęły przed „zadaniem budowania narodowej wspólnoty politycznej”, która niekiedy musi zostać wzniesiona od podstaw, aby umożliwić pełny udział w wartościach obywatelskich klasom wykluczonym. Pojęcie inkorporacji wartości obywatelskich przedstawiam za Jeffreyem C. Alexandrem (2006), który przenosi obawy Bendixa dotyczące pełnego udziału klas niższych we wspólnocie obywatelskiej na inne typy grup zewnętrznych. 
Po przeanalizowaniu interesujących nas kwestii możemy obecnie historycznie umiejscowić paradygmat dezorganizacji społecznej. Kategorie organizacji grupy pierwotnej, dezorganizacji społecznej i reorganizacji społecznej opierały się częściowo na historycznych doświadczeniach Polaków i Żydów, zgodnie z tym, jak je rozumieli Thomas i Znaniecki. Obie te społeczności kształtowały się w podobnych okolicznościach: bezpaństwowość (do 1918 r. u Polaków), diasporyczność, rozpad grup pierwotnych oraz trudy reintegracji w szerszych społecznościach narodowych, które same były w trakcie kształtowania się lub transformacji. Paradygmat społecznej dezorganizacji można zatem wyjaśnić częściowo poprzez analizę komparatystyczną: Thomas i pozostali naukowcy wykazali, że ma ona zastosowanie do Polaków, Żydów i wielu innych grup etniczno-narodowych doświadczających rozwoju kapitalistycznego i migracji. Niemniej jednak owe grupy etniczno-narodowe nie były wyłącznie podobnymi przypadkami społeczności powielających wspólny proces społeczny; funkcjonowały one również jako znaki w systemie semiologicznym. Oznacza to więc, że znaczenie teoretycznych kategorii paradygmatu - organizacja grupy pierwotnej, dezorganizacja społeczna i reorganizacja społeczna - wywodzi się też z partykularyzmów grup etniczno-narodowych w odniesieniu do wszystkich innych społeczności. Thomas i Znaniecki sformułowali powyższe kategorie teoretyczne w kontekście europejskim, poprzez porównanie ze sobą na zasadzie kontrastu portretów polskiego chłopa, dezorganizujących wspólnotę Żydów i budujących naród polskich elit. Mimo że Thomas i pozostali przypisali niektórym z tych grup nowe role społeczne w kontekście amerykańskim w którym to włoscy imigranci uosabiali organizację grupy pierwotnej, polski chłop był pogrążony w dezorganizacji społecznej, Żydzi zaś brali aktywny udział w rekonstrukcji wartości wspólnotowych - nadal próbowali wyjaśniać kategorie społeczne poprzez odniesienie do postrzeganych różnic między grupami etniczno-narodowymi.

Jedną z korzyści przeniesienia naszych rozważań na grunt historyczny jest ukazanie, w jaki sposób wiedza ludowa i uprzedzenia mogą wpływać na kategorie teoretyczne. Jest to widoczne na przykład w tym, jak Thomas i Znaniecki utożsamiali dezorganizację społeczną z działalnością żydowską i korzystali z antyżydowskich stereotypów, aby rozwinąć tę kategorię teoretyczną. W takich przypadkach naukowe odcięcie się od uprzedzeń lub niegdyś przyjętych sformułowań staje się niekompletne (Durkheim, 1982: 60-84; Bourdieu, Chamboredon i Passeron, 1991: 13-31). Jednak stwierdzenie istnienia tego rodzaju pozanaukowych wpływów nie wymaga 
bynajmniej odrzucenia paradygmatu dezorganizacji społecznej; jej kategorie są nadal funkcjonalne, nie należy zatem „burzyć fundamentów koncepcyjnych i zaczynać od nowa” ${ }^{19}$. Wykazanie ukrytego wpływu wiedzy ludowej i uprzedzeń należy traktować raczej jako wstęp do udoskonalenia wkładu naukowego Thomasa i Znanieckiego we współczesną socjologię.

Widać to zwłaszcza w sposobie, w jaki paradygmat społecznej dezorganizacji pomaga wyjaśnić, dlaczego próby inkorporacji grup zewnętrznych w budowanie społeczeństwa obywatelskiego nie zawsze się udają oraz jak można temu zaradzić. Polacy i Amerykanie stanęli w obliczu podobnych problemów we wczesnych dekadach XX w. - mianowicie w obliczu potrzeby wykształcenia szerszej (narodowej) społeczności i włączenia do niej członków ulegających rozkładowi grup pierwotnych - jednakże procesy te były kształtowane przez zróżnicowane warunki społeczne. Dla polskich elit nacjonalistycznych, żyjących w rejonie Europy od wieków odczuwającym skutki migracji, reorganizacja społeczna była przede wszystkim kwestią przekształcenia pozostałych chłopów w Polaków ${ }^{20}$. Poprzez aktywny udział w nowych instytucjach społecznych tworzonych przez inne klasy społeczne chłop miał współpracować w rozwoju ,jedności narodowej” i „kultury narodowej” (Thomas i Znaniecki, 1974: 1306). Ponieważ zaś Stany Zjednoczone były krajem przyjmującym imigrantów, reorganizacja społeczna w kontekście amerykańskim wiązała się z integracją nowych grup imigrantów, a nie z integracją chłopów z innymi klasami społecznymi. Wielu z tych nowych imigrantów miało, co prawda, chłopskie pochodzenie, lecz to właśnie ich różnorodne pochodzenie etniczne, religijne, narodowe i rasowe oddzielało ich od rdzennych Amerykanów i od siebie nawzajem. Ponadto, w przeciwieństwie do polskich elit nacjonalistycznych przed rokiem 1918, amerykańskie elity polityczne mogły stosować przymus władzy państwowej w celu propagowania i sterowania reorganizacją społeczną.

19 Julia Adams, Elisabeth S. Clemens oraz Ann Shola Orloff przedstawiają podobne stwierdzenie w odniesieniu do współczesności (2005: 14).

20 Jest to aluzja do słów Eugena Webera (1976). Polski chłop „musiał najpierw zdobyć wykształcenie oraz pojąć kwestie organizacji społeczeństwa obywatelskiego, żeby mógł w pełni zrozumieć i docenić cel przyświecający tworzeniu ideału narodowego” (Thomas i Znaniecki, 1974: 1308). Na kolejnych stronach autorzy wspominają o roli chłopa w życiu narodowym (Thomas i Znaniecki, 1974: 1432-1463). Park i Miller piszą w Old World Traits Transplanted: „Wspomniany chłop nie wiedział, że był Polakiem; pytany, zaprzeczył temu. To szlachcic był Polakiem, on od zawsze był tylko chłopem. Zanotowaliśmy wiele dowodów na to, że członkowie innych grup imigrantów dopiero po przybyciu do Ameryki zdali sobie sprawę ze swojej narodowości” (Park i Miller, 1921: 145-146). 
Najważniejszą konkluzją wyłaniającą się z lektury Chłopa polskiego... jest przeświadczenie o nieuchronnym końcu tradycyjnych form organizacji społecznej w momencie rozpoczęcia ich rozpadu; oznacza to, że reorganizacja społeczna jest jedyną realną alternatywą dla dezorganizacji społecznej i ani wykluczenie, ani przymus (nakazy i zakazy) nie są skutecznym środkiem reorganizacji. Jak można stwierdzić, odbudowa narodowa w Polsce podlegała ograniczeniom wskutek braku pełnej inkorporacji Żydów do społeczności polskiej (a co za tym idzie, także innych mniejszości narodowych lub religijnych) po 1918 r. Żydzi mogli być uważani za nieodpowiedni materiał do budowania narodu również z powodu powszechnie panującego przekonania o ich dezorganizującym wpływie. Jednak reorganizacja społeczna „nie jest kwestią wykorzenienia negatywnych tendencji, ale ciągłą próbą organizowania wszelkich tendencji w celu użyteczności społecznej” (Thomas i Znaniecki, 1974: 1799). Nawet postawy, które wydają się społecznie destrukcyjne, mogą, jeśli zostaną właściwie ukierunkowane, stać się „skutecznymi czynnikami społecznej rekonstrukcji” (Thomas i Znaniecki, 1974: 1300). Jeśli postawy te lub tendencje nie znajdują odpowiedniego wyrazu w istniejącym porządku społecznym, „problem nie polega na ich tłumieniu, lecz na znalezieniu dla nich instytucjonalnej ekspresji i wykorzystaniu ich w celach społecznie produktywnych” (Thomas i Znaniecki, 1974: 1121). Jak już wcześniej wspomniano, tego rodzaju rozwiązanie jest możliwe tylko poprzez komunikację, która umożliwia jednostkom i grupom społecznym dostrzeżenie innych, działających wraz z nimi w celu finalizacji wspólnych zamysłów.

Czy zatem lekcje zawarte w Chłopie polskim... miały skuteczniejszy wydźwięk w Stanach Zjednoczonych? W Old World Traits Transplanted Thomas i pozostali badacze przedstawili nowojorską organizację Kehilah i prasę publikowaną w jidysz jako udane przykłady społecznej reorganizacji w mniejszej, subnarodowej skali, która mogłaby stanowić model odbudowy narodowej w Stanach Zjednoczonych. „W przypadku społeczności żydowskiej”, pisali, „sprawdziła się demokratyczna kontrola nad spontanicznymi, przemyślanymi i świetnie zorganizowanymi eksperymentami społecznymi, które mogą posłużyć jako przykład w organizacji państwa amerykańskiego" (Park i Miller, 1921: 237-238). Jeśli ogromna, zróżnicowana i często podzielona nowojorska społeczność żydowska mogła odnieść sukces w kształtowaniu bardziej ekspansywnej i niewykluczającej formy wspólnoty w ramach demokratycznych i pluralistycznych zasad społecznych, to cała Ameryka mogła również tego dokonać. Niestety, zalecenia Thomasa i pozostałych badaczy w dużej mierze nie zostały wzięte pod uwagę. Stany Zjednoczone zamiast tego rozpoczęły przymusową i konformistyczną kampanię na rzecz 
amerykanizacji nowych imigrantów podczas I wojny światowej, a Kongres wysunął antysemickie i nacjonalistyczne żądania drastycznego ograniczenia imigracji w latach 1921 i 1924. W okresie gdy Żydzi w Polsce i pozostałych krajach Europy najbardziej potrzebowali pomocy, ograniczenia te nadal pozostawały w mocy. Krótko mówiąc, w USA, podobnie jak w Polsce, odbudowa narodowa została osłabiona przez zastosowanie wykluczenia społecznego wobec niektórych wspólnot.

Niektórzy sądzą z pewnością, że stwierdzenia zawarte w Chłopie polskim... straciły już na aktualności. Jednak prawie sto lat po ich opublikowaniu imigracja ponownie stała się społecznym punktem zapalnym zarówno w Europie, jak i Ameryce, przywódcy polityczni po obu stronach Atlantyku przyjęli podejście nacjonalistyczne jako ostateczne rozwiązanie problemów społecznych, a polityka państwowa, jak się wydaje, coraz bardziej polega na nakazach i zakazach. W tych okolicznościach najcenniejszym i trwałym wkładem Chłopa polskiego... mogą być proponowane przez autorów metody alternatywne oraz nadzieja, że dzieło to nadal będzie inspirować do odbudowy społeczności w szerszych, bardziej demokratycznych i pluralistycznych ramach.

\section{Literatura}

Adams, J., Clemens, E.S., Orloff, A.S. (2005). Social Theory, Modernity, and the Three Waves of Historical Sociology. W: J. Adams, E.S. Clemens, A.S. Orloff (red.), Introduction: Social Theory, Modernity, and the Three Waves of Historical Sociology (ss. 1-72). Durham: Duke University Press.

Alexander, J. (2006). The Civil Sphere. New York: Oxford University Press.

Anderson, B. (1991). Imagined Communities: Reflections on the Origin and Spread of Nationalism. New York: Verso.

Bellair, P. (2017). Social Disorganization Theory. W: Oxford Research Encyclopedia of Criminology, http:// criminology.oxfordre.com/view/10.1093/acrefore/9780190264079.001. 0001/acrefore-9780190264079-e-253, dostęp: 18.11.2018.

Bendix, R. (1996). Nation-Building and Citizenship: Studies of Our Changing Social Order. New Brunswick, NJ: Transaction.

Bourdieu, P. (2008). Political Interventions: Social Science and Political Action. New York: Verso.

Bourdieu, P., Chamboredon, J.C., Passeron, J.C. (1991). The Craft of Sociology: Epistemological Preliminaries. New York: Walter de Gruyter.

Bressler, M. (1952a). Jewish Behavior Patterns as Exemplified by W.I. Thomas'Unfinished Study of the Bintl Brief, niepublikowana rozprawa doktorska, Philadelphia: University of Pennsylvania.

Bressler, M. (1952b). Selected Family Patterns in W. I. Thomas' Unfinished Study of the Bintl Brief, American Sociological Review, 17 (5), 563-571. 
Calhoun, C. (1996). The Rise and Domestication of Historical Sociology. W: T.J. McDonald (red.), The Historic Turn in the Human Sciences (ss. 305-337). Ann Arbor: University of Michigan Press.

Carey, J.T. (1975). Sociology and Public Affairs: The Chicago School. London: Sage.

Cooley, Ch.H. (1925). Social Organization: A Study of the Larger Mind. New York: Charles Scribner's Sons.

Dewey, J. (1954). The Public and Its Problems. Athens: Ohio University Press.

Durkheim, È. (1982). The Rules of Sociological Method. New York: Free Press.

Elias, N. (1978). The Civilizing Process: The Development of Manners. New York: Urizen Books.

Faris, R.E.L. (1967). Chicago Sociology, 1920-1932. Chicago: University of Chicago Press.

Fink, C. (2004). Defending the Rights of Others: The Great Powers, the Jews, and International Minority Protection, 1878-1938. New York: Cambridge University Press.

Gartner, L.P. (2001). History of the Jews in Modern Times. New York: Oxford University Press.

Goldberg, Ch.A. (2017). Modernity and the Jews in Western Social Thought. Chicago: University of Chicago Press.

Goren, A.A. (1970). New York Jews and the Quest for Community: The Kehilah Experiment, 1908-1922. New York: Columbia University Press.

Janowitz, M. (1966). Introduction. W: M. Janowitz (red.), On Social Organization and Social Personality. Chicago: University of Chicago Press.

Janowitz, M. (1975). Sociological Theory and Social Control. American Journal of Sociology, 81 (1), 82-108.

Matthews, F.H. (1977). Quest for an American Sociology: Robert E. Park and the Chicago School. Montreal: McGill-Queen's University Press.

Mendelsohn, E. (1983). The Jews of East Central Europe Between the World Wars. Bloomington: Indiana University Press.

Park, R.E. (1922). The Immigrant Press and Its Control. New York: Harper \& Brothers.

Park, R.E., Miller, H.A. (1921). Old World Traits Transplanted. New York: Harper \& Brothers.

Simmel, G., Levine, D.N. (1971). On Individuality and Social Forms. Chicago: University of Chicago Press.

Thomas, W.I. (1966). Analytical Types: Philistine, Bohemian, and Creative Man. W: M. Janowitz (red.), On Social Organization and Social Personality. Chicago: University of Chicago Press.

Thomas, W.I., Znaniecki, F. (1974). Polish Peasant in Europe and America, t. 2. New York: Farrar, Straus and Giroux.

Vital, D. (1999). A People Apart: The Jews in Europe, 1789-1939. New York: Oxford University Press.

Weber, E. (1976). Peasants into Frenchmen: The Modernization of Rural France, 1870-1914. Stanford: Stanford University Press.

Tłumaczenie dr Alicja Żuchelkowska

Tłumaczenie zostało sfinansowane ze środków

Fundacji Naukowej im. Floriana Znanieckiego 
